Ирина Абрамова*

Лариса Жуковская**

Нижегородский государственный

университет им. Н.И. Лобачевского***

(Россия, Нижний Новгород)

\title{
ЯЗЫКОВАЯ ОБЪЕКТИВАЦИЯ КОНЦЕПТА “МЕНТАЛИТЕТ/МЕНТАЛЬНОСТЬ" В СОВРЕМЕННОЙ РУССКОЙ И СЕРБСКОЙ РЕЧИ: СОПОСТАВИТЕЛЬНЫЙ АСПЕКТ
}

\section{Аннотация}

Рассматриваются особенности языковой объективации когнитивных признаков концепта «менталитет / ментальность» в дискурсивных практиках носителей современного русского и сербского языков как значимый показатель языкового освоения этого концепта, обозначаемого словами 'менталитет' и 'ментальность', в современном русском языковом сознании в сопоставлении с современным сербским.

Ключевые слова: Концепт «МЕНТАЛИТЕТ / МЕНТАЛЬНОСТЬ»; когнитивные признаки; дискурс; концептуальный анализ; современный русский язык; сербский язык; сопоставительный аспект.

Статья посвящена выявлению особенностей языкового воплощения концепта «менталитет/ментальность» в фактах современного русского языка последних лет по данным словарей и его текстовой реализации по данным Национального корпуса русского языка, с одной стороны, - и концепта МЕНТАЛИТЕТ в сербском языке по данным словарей и Интернет-мониторинга, с другой.

\footnotetext{
* irabra@yandex.ru

**Ilara_nn@mail.ru

*** Нижегородский государственный университет им. Н.И. Лобачевского, просп. Гагарина, 23, Нижний Новгород, Нижегородская обл., Русија, 603022
} 
В наше время все отчетливее заявляют о себе стратегии научного поиска, связанные с антропоцентрическим подходом к изучению явлений языка и текста. С конца 80 -х — начала 90-х гг. XX в. в российской и зарубежной лингвистике формируется лингвокультурологическая парадигма научного знания, ориентированная на изучение взаимосвязи феноменов языка и национальной культуры. Одним из самых значимых направлений в современной лингвокультурологии является концептуальный анализ-методология и методика изучения ключевых концептов культуры, отражающих этно-обусловленные модели восприятия мира, ценностные ориентиры и речеповеденческие установки и стереотипы.

В этой связи представляется особенно важным изучение таких концептов, которые отражают ведущие тренды в современной цивилизации, а именно ориентацию на поиск национальной идентичности, стремление к сбережению уникальности и самобытности каждого этноса, населяющего нашу планету. К такого рода концептам, несомненно, относится концепт менталитет /ментальность, который является удачным обобщающим обозначением таких давно воспринятых в культурной традиции, но не имеющих единого и общепринятой терминологической номинации понятий, как "дух народа», «народное мировоззрение/мироощущение», «национальный характер» и пр.

При этом указанные явления ощущаются как безусловная психологическая реальность нашего духовного и культурного опыта, что отражено в речевой практике языкового сообщества, в совокупности того, что говорится и понимается на национальном языке.

В работе использовалась методика концептуального анализа, разработанная на кафедре преподавания русского языка в других языковых средах филологического факультета ННГУ им. Н.И. Лобачевского (Горшкова, Ручина 2004; Сайгин 2013а, 20136, 2015; Ручина 2014; Радбиль, Сайгин 2014). Сначала было выявлено содержание понятия менталитет/ментальность в русском языке и менталиmem в сербском языке в экстралингвистическом аспекте - для этого мы используем данные научных монографий, статей, а также философских словарей и энциклопедий. Затем было проанализировано его смысловое содержание, представленное в системе языка по данным разнообразных словарей. Для большей адекватности описания мы использовали и сопоставительный аспект анализа с ориентацией на язык-источник (в нашем случае - латинский) и языки-посредники 
(современные английский, французский и немецкий языки), потому что ряд когнитивных признаков языка-источника и языков-посредников вступают во взаимодействие с признаками, выработанными национальным сознанием в рамках национальной концептосферы.

Сегодня концепт менталитет/ментальность в русском языке и менталитет в сербском является репрезентативным выразителем важных духовных, культурных, этических ценностей этноса, социальной, профессиональной или культурной группы, отдельной личности. Об этом свидетельствует значительная активизация терминов менталитет (ментальность) в современной русской речи, особенно в языке СМИ или в политическом дискурсе.

В результате анализа были получены следующие результаты.

В русском языке в обыденном употреблении на сегодняшний день трудно установить существенную семантическую, стилистическую или функциональную дифференциацию между понятиями МЕНТАЛИТЕТ и МЕНТАЛЬНОСТЬ. Особенностью этого концепта является его воплощение в недифференцированном употреблении двух лексем - менталитет и ментальность, что привело нас к необходимости двойного наименования исследуемого концепта как менталитет/ментальность.

По данным словарей, в сербском языке не зафиксирована лексема МЕНТАЛЬНОСТЬ. Научный же термин менталитет сегодня внедряется в массовый языковой обиход и проходит стадию «популяризации», что приводит к частичному размыванию его семантики и расширенному употреблению его в несвойственных ему изначально значениях. Однако в сербском языке данный процесс, по всей вероятности, находится еще на первоначальной стадии, о чем свидетельствует количественное отличие в когнитивных признаках данного концепта: 11 в русском и 8 в сербском языке. Будучи представленным, как и в русском языке, иноязычным по происхождению словом, данный концепт выступает как пример явления «импорта концепта» (Карасик: 3-16), поэтому на его семантику влияют значения слов-эквивалентов в языке-источнике (латынь) и в современных западноевропейских языках.

По данным научных источников, энциклопедий, философских словарей, а также основных толковых словарей было выявлено 11 когнитивных признаков концепта менталитет / ментальность в лексико-семантической системе современного русского языка и 8 в сербском: 


\begin{tabular}{|c|c|}
\hline Русский язык & Сербский язык \\
\hline $\begin{array}{l}\text { 1. Образ мыслей, образ мышления (складума) } \\
\text { События, произошедшие в этом городе, } \\
\text { повлияли на самый образ мыслей россиян, } \\
\text { изменив их менталитет (патриарх Алек- } \\
\text { сий ІІ (Ридигер). Доклад Патриарха Москов- } \\
\text { ского и всея Руси Алексия (2004) //«Журнал } \\
\text { Московской патриархии», 2004.10.25) } \\
\text { 2. Способ видения мира (мировидение) } \\
\text { 3. Единый нерасчлененный комплекс ви- } \\
\text { дения мира, системы ценностей и моделей } \\
\text { поведения, образ жизни } \\
\text { 4. Особенности психической жизни, нацио- } \\
\text { нальный характер } \\
\text { Но есть и другая -может быть, более важ- } \\
\text { ная, которая коренится в человеческой пси- } \\
\text { хике, в менталитете: интуитивная тяга к аб- } \\
\text { страктно понимаемым свободе и равенство } \\
\text { для всех и во всем, породившая и христиан- } \\
\text { ство, и коммунистические утопии каждод- } \\
\text { невно рождающая } \\
\text { Социальную зависть и ненависть (Анатолий } \\
\text { Собчак. Дюжина ножей в спину (1999)) } \\
\text { 5. Регулятор нормативного отношения к } \\
\text { миру и поведения } \\
\text { 6. Образный, верифицируемый, в извест- } \\
\text { ном смысле иррациональный тип интел- } \\
\text { лектуальной / психической реакции на дей- } \\
\text { ствительность } \\
\text { 7. Неосознанный, спонтанный, имплицит- } \\
\text { ный характер бытования. } \\
\text { 8. Картина мира (образ мира, модель мира) } \\
\text { 9. Знаковый (семиотический) способ функ- } \\
\text { ционирования } \\
\text { 10. Принадлежность определенного объе- } \\
\text { динения, общности людей по националь- } \\
\text { ному пли социальному признаку } \\
\text { 11. Принадлежность индивидуума }\end{array}$ & $\begin{array}{l}\text { 1. Совокупность духовных навыков, иде- } \\
\text { алов и ценностей - духовно устројство, } \\
\text { скуп духовних особина } \\
\text { 2. Образ мыслей, образ мышления (склад } \\
\text { ума) - начин мишљења } \\
\text { 3. Единый нерасчлененный комплекс ви- } \\
\text { дения мира, системы ценностей и моделей } \\
\text { поведения, образ жизни - поглед на свет } \\
\text { Немојте кривити њихов поглед на свет, } \\
\text { њихов менталитет, њихову личност } \\
\text { 4. Особенности психической жизни, наци- } \\
\text { ональный характер - али менталитет } \\
\text { опсаде води упораз } \\
\text { 5. Проявление в культуре } \\
\text { и под изменением менталитета я подразу- } \\
\text { меваю - и врста културне промене која је } \\
\text { неопходна пока мы не изменим наш мен- } \\
\text { талитет - ако не променимо нашу кул- } \\
\text { туру } \\
\text { 6. Картина мира (образ мира, модель } \\
\text { мира) - Это был революционный период } \\
\text { времени, характеризующийся отказом } \\
\text { от традиционных нравов, употреблени- } \\
\text { ем наркотиков и умонастроением «все } \\
\text { дозволено» - То је био револуционарни пе- } \\
\text { риод кога је карактерисало одбацивање } \\
\text { традиционалног морала, коришћење } \\
\text { дрога, и менталитет „све је дозвољено”. } \\
\text { 7. Принадлежность определенного объе- } \\
\text { динения, общности людей по националь- } \\
\text { ному пли социальному признаку } \\
\text { Српски менталитет савршено описан на } \\
\text { једном примеру } \\
\text { 8. Принадлежность индивидуума } \\
\text { Новак нема више победнички ментали- } \\
\text { тет. Из прве ћете погодити ко је ово рекао } \\
\text { о српском тенисеру } \\
\text { Момо Капор је дуго година је проучавао } \\
\text { менталитет својих сународника }\end{array}$ \\
\hline
\end{tabular}

Как видим, разница наблюдается не только в самом количестве признаков, но и в их распределении.

Существует отличие в семантике лексемы МЕНТАЛИТЕТ в сербском языке относительно западноевропейских. Анализ западноевропейских лексических эквивалентов этой иноязычной лексемы (фран- 
цузского mentalité, немецкого Mentalität, английского языке mentality и др.) выявил ориентацию его семантики исключительно на деятельность сознания, разума, интеллекта. В целом мы можем постулировать наличие некоторых инвариантных семантических признаков этой интернациональной лексемы в разных европейских языках именно в силу их принадлежности к общему культурному фонду. Это такие предельно общие признаки, как 'склад ума', 'образ мыслей'.

В сербском языке духовная и рациональная составляющая в семантике равны. Интересно, что разные в хронологическом отношении словари отражают динамику изменения в значении лексемы:

1. менталитет, ета, м.- 1. начин мишљења, 2. скуп душевних особина и склонности једног человека или едне људске заједнице: у стиховима је износио карактер и ментаљитет словенског сељака (Речник 1969)

2. менталитет (нлат. mentalis, фр. mentalite) целокупне духовно устројство - начин мишљења, схватања, склоности, расположења и др. - једног човека, друшственог реда, поколења итд., душевно стање, духовна настројеност (Милан Вујакија 1986).

2. менталитет, м 1. скуп духовних особина припадника једне заједнице, 2. карактеристична својства уопште

\section{Синоними:}

1. карактер, темперамент, сензибилитет, ков, природа, душа, дух, психологија

2. карактер, темперамент, природа, эго, личност, душа, ћуд, дух, сензибилитет, психа, психологија, ков, нарав, индивидуалност, индивидуалитет, настројеност, нутрина, ја, особине, унутрашњост, фриг.

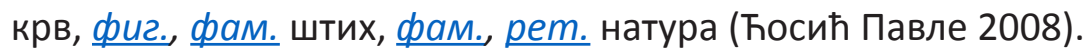

Следующий этап анализа предполагает выявление особенностей употребления слов-репрезентантов данного концепта в речевой практике современных носителей языка. Теоретическим обоснованием этого подхода являются следующие соображения. Согласно современным подходам когнитивной лингвистики и концептуального анализа, максимально полное описание таких явлений, как концепты, представляющие собой определенные структуры знаний, должно быть комплексным: при этом необходимо различать экстралингвистическое содержание концепта, включающее онтологические, мыслительные, аксиологические и прагматические компоненты, и 
собственно лингвистическую семантику слов -- репрезентантов концепта, реализованную в парадигматических, синтагматических и деривационных особенностях их функционирования, как это обосновывается, например, в работе (Радбиль 2006).

Итак, нас интересуют особенности синтагматической и парадигматической реализации слов - репрезентантов концепта менталиmет / ментальность в реальном языковом употреблении. Материалом для анализа служат данные Национального корпуса русского языка - на настоящий момент важнейшего источника языковых фактов для анализа когнитивных признаков и языковой экспликации национально-обусловленных концептов, особенно в плане учета специфики их функционирования в современной русской речи. По данным Национального корпуса русского языка мы предполагаем описать основные модели расширения концептуального содержания и изменений в языковой экспликации концепта менталитет / ментальность в русском языке последних лет.

Языковое освоение концепта менталитет / ментальность в контекстах, в основном представляющих язык СМИ и Интернет-коммуникации, а также некоторые области политического дискурса, обнаруживает общие тенденции языковой концептуализации понятий абстрактного типа, которая осуществляется по моделям концептуальной метафоризации, описанным в работе Дж. Лакоффа и М. Джонсона (Лакофф, Джонсон 2004). Данный концепт, сохраняя свое инвариантное, базовое содержание, может существенно изменять свою оценочно-коннотативную сферу, преобразовывать смысловые связи и отношения между ними и т. д.

Данные Национального корпуса русского языка, с одной стороны, демонстрируют активность в речевой практике выявленных по данным словарей когнитивных признаков, а с другой стороны, обнаруживаются некоторые новые когнитивные признаки концепта менmaлитет / ментальность, возникающие на базе исходных значений под воздействием изменившейся экстралингвистической среды (новое понимание, новый взгляд на содержание данного концепта). Кроме того, существенно расширяется сочетаемость слов, репрезентирующих концепт менталитет / ментальность и, как следствие этого, растет его метонимический и метафорический потенциал, образуются новые контекстные синонимические ряды и антонимические пары. 
В целом данные Национального корпуса русского языка подтверждают выявленные ранее когнитивные признаки данного концепта. Как и ожидалось, основной массив примеров связан с выражением национальной характеристики менталитета: русский менталитет, кавказский менталитет, чеченский, тюркский и пр. При этом отметим, что и при сохранении ядерных когнитивных признаков современные употребления менталитет/ ментальность существенно расширяют свою сочетаемость, в результате чего слово может быть применимо по отношению к любым общностям людей, выделенным по любому значимому признаку (менталитет вдов, менталитет холостяков, менталитет стариков, менталитет футболистов и пр.).

В обследованном материале встретился ряд примеров, которые демонстрируют разного рода языковые преобразования слов менталитет / ментальность. Мы условно делим их на две группы: (1) явления семантических преобразований и (2) явления преобразований в коннотативно-оценочной сфере.

I. Семантические преобразования. Это случаи разного рода концептуальной метафоризации или метонимизации слов менталитет/ ментальность.

1.1. Метафоризация. Основные случаи метафоризации осуществляются по модели концептуальной метафоры [5] и связаны с представлением абстрактного понятия в качестве существа, конкретного объекта, вещества, субстанции и т. д.

Так, в следующих примерах менталитет предстает в виде членимого, делимого физического объекта:

И этой позицией между Азией и Европой, которая растаскивает менталитет на два куска (Андрей Битов. Русский устный и русский письменный // «Звезда», 2003);

И понимал: менталитет разведен, раздвоен на две половины (Андрей Битов. Русский устный и русский письменный // «Звезда», 2003).

В другом примере менталитет приобретает предикативные признаки, присущие в норме живому существу:

Она лучше образована. Ее менталитет исключительно гибок, изворотлив, приспособителен. Она умеет скрывать свою натуру, представлять свое поведение в наилучшем свете и нахо- 
дить оправдания (Александр Зиновьев. Русская судьба, исповедь отщепенца (1988- 1998).

В некоторых случаях менталитет используется в модели зоологической метафоры:

У Рейчухи менталитет крокодила, она действует бесшумно и мгновенно, а зубам собачки позавидует акула (Дарья Донцова. Уха из золотой рыбки (2004)).

I.2. Метонимизация. Часто слова менталитет/ментальность употребляются метонимически. Это возможно, например, в атрибутивных сочетаниях (прил. + сущ.):

Цирровой менталитет (Заголовок статьи, Январь 2014, Нина Важдаева, сайт агроинве-стор). - Имеется в виду менталитет пользователей и производителей цифровых устройств.

Однако чаще всего метонимия используется в модели генитивного сочетания с неодушевленным существительным (сущ. + сущ.), например:

Эксперты призывают Москву и Вашингтон не допустить «юридического вакуума» по истечении срока действия договора CHB-1, не провалить предстоящую конференцию по Договору о нераспространении ядерного оружия (как это произошло в 2005 году), а главное, окончательно выкорчевать менталитет "холодной войны» (Вячеслав Леонов. Потрепали по боеголовке (23.04.2009) // http:// www.luxembourgforum.org/press/smi/potrepali-po-boegolovke/, 2009).

Имеется в виду - менталитет общества в условиях «холодной войны» или людей, живущих в ситуации «холодной войны».

Та же модель используется в следующем примере:

Люди с менталитетом дефицита с огромным трудом делятся с другими: признанием или доверием, властью или выгодой, - даже если эти другие участвовали в производстве продукта. Они не умеют искренне радоваться чужим успехам и даже (а иногда особенно) успехам членов своей семьи, близких друзей и сослуживцев. Как будто, если на другого сваливается известность или неожиданное богатство, это отнимается у них самих. Люди с менталитетом дефицита втайне надеются, что других постигнет несчастье: не обязательно что-то ужасное, но хотя бы относительная напасть, которая "поставит их на место». Они вечно 
сравнивают, конкурируют, тратят массу энергии на то, чтобы завладеть вещами или людьми и таким образом повысить свое чувство значимости (Менталитет изобилия и менталитет дефицита. 21 апреля 2013 г., Рубрика Психология/грани себя).

Менталитет дефицита / изобилия следует трактовать как менталитет общества изобилия или дефицита.

II. Преобразования в коннотативно-оченочной сорере. Эти преобразования связаны с возможностью приобретения отвлеченным и безоценочным понятием менталитет/ментальность потенциальной положительной или отрицательной оценочности за счет сочетаемости с оценочными или эмоционально-экспрессивными прилагательными. Отметим, что в работах Т.Б. Радбиля такие явления справедливо рассматриваются как «аксиологические аномалии» (как вариант «аномалий языковой концептуализации мира») (Радбиль 2005, 2006, 2007). Однако, с другой стороны, приобретение внеоценочными лексемами разнообразных ценностных коннотаций, видимо, является обычным способом естественно-языковой концептуализации абстрактных понятий.

Итак, каким же может быть менталитет/ментальность в обыденном языковом сознании носителей языка?

Он может быть трусливым, дурным, испорченным, невиданным, идиотским и пр.:

Близорукая стратегия Японии - трусливый менталитет самообмана (Заголовок статьи, 13.07.2012 Жэньминь жибао);

У тебя дурной менталитет, мне «все равно» на твои традиции, я тунисеи, ты обязана все делать так, как скажу я. Если я прошу его показать мне конкретно где в Коране то, что он приказывает делать, он отвечает: "Я не забочусь об этом, я так хочу. Я выме, ты ниже, я главный, ты ...» (Статья «Проблема национальных браков, 04.06.2010 г., публикация на сайте http://www.info-islam.ru);

Испорченная ментальность: миазм извращает, деформирует, портит рассудок, хочет все скрывать, даже собственные болезни (коллективный. Классическая гомеопатия и шарлатанство (2008-2010));

Это - совершенно новый и несообразно дикий образ жизни, совершенно новый невиданный менталитет (Борис Стругацкий. Мы сейчас на очень опасном вираже истории (2001)); 
Просто когда размениваешься - потом такая пустота, словно не жила на свете. Может, у нас менталитет такой идиотский. Ну, не можем мы быть счастливы, когда много (Елена Исаева. Убей меня, любимая! (2002)).

Очень часто оценка и эмоционально-экспрессивный фон соединяются с социальной или политической характеристикой - в таком случае возникает оценочность сложной природы:

Казарменный менталитет крепких парней (Переводная статья из польской газеты «Rzeczpospolita», Польша, 10.01.2014);

Уже не 7, а 27 лет я вдалбливаю в родной рабский менталиmет то, чего никак он не вместит (Владимир Леонович. Продолжение диалога (1999) // «Дружба народов», 15.04.1999);

Путин лично приложил немало сил к продавливанию реформы через косный красноватый менталитет бывщего партхозактива, а ныне буржуазной элиты (Светлана Бабаева, Георгий Бовт. Теорема Путина-Лобачевского. Признаки скорого дефолта (2002) // «Известия», 14.07.2002).

В результате получается, что в обыденном сознании носителя русского языка менталитет/ментальность могут быть «плохими» и "хорошими». Это еще одно проявление овеществления абстракции, которое свойственно всем отвлеченным понятиям в «наивной» языковой картине мира.

Как мы отметили, в сербском языке лексема, эксплицирующая данный концепт, еще не так активно употребляется вне своего терминологического значения, поэтому разного рода языковые преобразования слова менталитет, которые свойственны этим лексемам в русском языке, в сербском еще не проявились.

Наш материал не выявил случаев разного рода концептуальной метафоризации или метонимизации слова менталитет в сербском языке. Однако преобразования в коннотативно-оценочной сфере, связанные с возможностью приобретения отвлеченным и безоценочным понятием менталитет потенциальной положительной или отрицательной оценочности за счет сочетаемости с оценочными или эмоционально-экспрессивными прилагательными уже обнаруживаются:

Веселин Чајкановић, највећи српски етнолог, записао је да је сваки народ везан за понеку животињу, и у извесном смис- 
лу изједначен са њом. ... Тај „вуков“ устанак против „модерне цивилизације Запада" која још афирмише потрошачки менталитет, обезличавање човека и породице уз стварање плашљивих и кукавних људи неспособних да се за било шта добро и часно боре и изборе, као да најупорније бране и заступају управо Срби.(Култ вука у српском народу (19.3.2013)// http://srpska.ru/article.php?nid=20551)

Рајински и малограђански менталитет код Срба (Како је код срба пропао антикомунизам (14.07.2015) // https://srbin. info/2015/08/14/kako-je-propao-antikomunizam/)

Ако ме питате ко је главни фаворит да освоји турнир, то је сигурно Новак.Он има победнички менталитет који је додатно усавршио и сада га је тешко победити - признао је Швајцарац (Novak Đoković: Postaviću novi record (s.a)// https://story.rs/story-cafe/ novak-dokovic-postavicu-novi-rekord/)

Да морамо да преобразимо губитнички менталитет (https:// sr.glosbe.com/sr/ru/\%D0\%BC\%D0\%B5\%D0\%BD\%D1\%82\%D0\%B0\%D0\%B B\%D0\%B8\%D1\%82\%D0\%B5\%D1\%82 (s.a.)

Слово менталитет приобретает в сербском языке и возможность выражать оценочную реакцию говорящего. Однако, в отличие от русского языка, существует не только противопоставление СВОЙ - чУЖоЙ, но и противопоставление более конкретизирующее, свидетельствующее о том, что сербы считают себя частью балканского мира в целом, противопоставляя себя миру европейскому - БАЛКАНСКИЙ - ЕВРОПЕЙСКИЙ.

Srpski mentalitet je moj mentalitet. Kada sam došao u Srbiju, shvatio sam da je to zemlja za mene. U rodnom Parizu sam se osećao kao stranac. Nisi došao sam, doveo si i ćerku Lunu sa sobom. Misliš da je Srbija bolje mesto za njeno odrastanje nego Francuska? Svakako! Ovde je veoma bezbedno, bezbednije nego u Parizu. Kada sam prvi put došao u Srbiju, video sam mladi bračni par sa detetom ispred supermarketa. Roditelji su ušli u supermarket, a dete je ostalo napolju da se igra (Stranci otkrivaju šta in Šokira u Srbiji: Evo šta ih je iznenadilo kod naše policije, kome ćevapi deluju kao go.no na tanjiru, ko se osetio kao da je špijun...(01/05/2018)// www.kurir.rs/vesti/drustvo/3041367/stranci-otkrivaju-sta-ih-sokira-usrbiji-evo-sta-ih-je-iznenadilo-kod-nase-policije-kome-cevapi-deluju-kaogono-na-tanjiru-ko-se-osetio-kao-da-je-spijun) 
Проведенное исследование показало значимость концепта менталитет/ментальность в современной национальной концептосфере как русского, так и сербского языков, его успешное освоение в речевой практике носителей языка, не только в научном, но и в публицистическом и даже художественном дискурсе, однако в русском языке наблюдается большая его культурная проработанность, что связано, безусловно, с традицией употребления его русскими философами. В сербском же языке культурные приращения не выработаны.

\section{Источники и литература}

Горшкова Т.М., Ручина Л.И. Концептосфера русской народной сказки и практика преподавания русского языка как иностранного // Вестник Нижегородского университета им. Н.И. Лобачевского. Серия: Филология. 2004. № 1. С. 152 157.

Карасик В.И. Культурные доминанты В языке / В.И. Карасик // Языковая личность: культурные концепты: Сб. научн. тр. - Волгоград-Архангельск: ВГУ, 1996. - С. 3-16.

Лакофф, Дж Метафоры, которыми мы живем: Пер. с англ. [Текст] / Дж. Лакофф, М. Джонсон. - М.: Едиториал, 2004. - 256 с.

Milan Vujaklija. Leksikon stranih reči i izraza. Beogradski izdavačko-grafički zavod, Beograd, 1986

Сайгин В.В. Концептуальное поле «грех» в пространстве русской культуры: опыт комплексного линвгокогнитивного описания: монография. Н. Новгород: Изд-во ННГУ им. Н.И. Лобачевского, 2015. 258 с.

Сайгин В. В. Когнитивные признаки и языковая экспликация концепта «грех» В современном русском языке: дис. ... канд. филол. наук. Киров, 2013а. 196 с.

Сайгин В. В. Языковая экспликация концепта «грех» в современном русском языке // Вестник Воронежского государственного университета. Серия: Лингвистика и межкультурная коммуникация. 20136. № 2. С. 112-116.

Радбиль, Т.Б. Норма и аномальность в парадигме «реальность - текст»/ Т.Б. Радбиль // Филологические науки. — 2005. - №1. - С.53-63.

Радбиль, Т.Б. Языковая аномальность в русской речи: к проблеме типологии [Текст] / Т.Б. Радбиль // Русский язык в научном освещении. — 2006. — №1 (11). C. $77-100$.

Радбиль, Т.Б. Аномалии в сфере языковой концептуализации мира [Текст] / Т.Б. Радбиль // Русский язык в научном освещении. - 2007. - №1 (13). - С. 239-265.

Радбиль Т.Б., Сайгин В.В. Особенности парадигматической и синтагматической реализации концептуального поля «грех» в современном русском языке // 
Современные проблемы науки и образования. 2014. № 5. URL: Шрз://аaа. science-education.ru/119-15195 (дата обращения: 27.11.2014).

Речник српскохрватскога книжевног језика: Матица српска, Матица хрватска, Загреб, Нови Сад, 1969

Ручина Л.И. Когнитивный анализ концепта и семантизация лексики // Динамика языковых и культурных процессов в современной России: материалы IV Конгр. РОПРЯЛ (Сочи, 1-2 нояб. 2014 г.): в 4 т. / редкол.: К.А. Рогова и др. СПб.: РОПРЯЛ, 2014. Т. 1. С. 168-172.

Ћосић, Павле. Речник синонима / Павле Ћосић и сарадници. - Београд : Kornet, 2008

\author{
Irina Abramova \\ Larisa Zhukovskaya \\ Lobachevsky State University of Nizhny Novgorod \\ Nizhni Novgorod, Russia
}

\title{
LINGUISTIC OBJECTIFICATION OF THE CONCEPT OF MЕНТАЛИТЕT/MЕНТАЛЬНОСТЬ (MINDSET/ MENTALITY) IN MODERN RUSSIAN AND SERBIAN SPEECH: COMPARATIVE ASPECT
}

\section{Summary}

The article reviews the specific features of linguistic objectification or the cognitive criteria or the concept «менталитет/ментальность» («mindset/mentality») in the discursive practices of native speakers of the modern Russian and Serbian languages a a significant indicator of the linguistic acquisition of the concept denoted by the words 'менталитет' ('mindset') and 'ментальность' ('mentality') in the modern Russian linguistic consciousness in relation to modern Serbian consciousness.

Key words: "MINDSET/MENTALITY», concept; cognitive criteria; discourse; conceptual analysis; contemporary Russian language; Serbian language; comparative aspect. 